\title{
Correction to: A new roadmap for the breeding of disease-resistant and high-yield crops
}

Yiming Wang ${ }^{1,2^{*}}$ and Suomeng Dong ${ }^{1,2^{*}}$

Correction to: Stress Biol 1, 21 (2021)

https://doi.org/10.1007/s44154-021-00023-0

Following publication of this article (Wang \& Dong, 2021), it is reported that this article contained two errors.

1. The name of the 2nd author should be 'Suomeng Dong' and this has been reflected in this Correction;

2. The reference 'Hout B et al., 2014' and its corresponding citation should be removed.

The original article has been updated.

\section{Author details}

${ }^{1}$ Key Laboratory of Biological Interaction and Crop Health, Department of Plant Pathology, Nanjing Agricultural University, Nanjing 210095, China. ${ }^{2}$ Key Laboratory of Integrated Management of Crop Disease and Pests, Ministry of Education, Nanjing Agricultural University, Nanjing, China.

Published online: 11 February 2022

\section{Reference}

Wang Y, Dong S (2021) A new roadmap for the breeding of disease-resistant and high-yield crops. Stress Biol 1(1):21. https://doi.org/10.1007/s44154-02100023-0

The original article can be found online at https://doi.org/10.1007/s44154021-00023-0.

* Correspondence: ymwang@njau.edu.cn; smdong@njau.edu.cn

${ }^{1}$ Key Laboratory of Biological Interaction and Crop Health, Department of Plant Pathology, Nanjing Agricultural University, Nanjing 210095, China Full list of author information is available at the end of the article

\section{Springer}

๑ The Author(s). 2022 Open Access This article is licensed under a Creative Commons Attribution 4.0 International License, which permits use, sharing, adaptation, distribution and reproduction in any medium or format, as long as you give appropriate credit to the original author(s) and the source, provide a link to the Creative Commons licence, and indicate if changes were made. The images or other third party material in this article are included in the article's Creative Commons licence, unless indicated otherwise in a credit line to the material. If material is not included in the article's Creative Commons licence and your intended use is not permitted by statutory regulation or exceeds the permitted use, you will need to obtain permission directly from the copyright holder. To view a copy of this licence, visit http://creativecommons.org/licenses/by/4.0/. 